\title{
Development of Mathematics Learning Device with Scaffolding-assisted Problem Approach to Improve Character Learners
}

\author{
Arif*, Patta Bundu, Nurdin Arsyad \\ Department of Educational Science, Universitas Negeri Makassar, Indonesia
}

Received March 9, 2020; Revised May 7, 2020; Accepted May 13, 2020

Copyright $\bigcirc 2020$ by authors, all rights reserved. Authors agree that this article remains permanently open access under the terms of the Creative Commons Attribution License 4.0 International License

\begin{abstract}
This research is a research and development that aims to determine the level of validity, practicality, and effectiveness of the results of the development of mathematics learning tools with a scaffolding-assisted problem-posing approach. The procedure for developing learning tools is done by adapting the 4-D model from (1) which consists of the steps of define, design, develop, and disseminate. The research subjects were 27 students of class VIII of SMP Negeri 1 Sindue in Donggala Regency. The results showed that the learning tools which included: lesson plans, student activity sheets, and learning outcome assessment instruments were in the very valid category, while the teacher's books and students' books were in the valid category; learning tools developed meet practical criteria because the ability of teachers to manage learning in both categories and the teacher's response to the use of learning tools is positive; learning tools are declared effective, because an increase in the character of students, student learning outcomes are completed classically; Student activities reach ideal criteria, and students respond positively to learning tools.
\end{abstract}

Keywords Learning Tools, Problem Posing, Scaffolding, Characters

\section{Preliminary}

Mathematics as one of the compulsory subjects is taught at all levels of education; of course, it is necessary to inculcate more intensive concepts and attitude growth since primary education. In the 2013 curriculum content standards, it is emphasized that to master and create future technology, mastery of mathematical concepts is needed from an early age (2). Therefore, mathematics learning is directed at the formation of thinking abilities and personalities that lead to the ability to use mathematics as a language and a tool to solve problems in their lives.

But in reality, student's mastery of mathematics, especially in basic education still raises concerns. Mathematics is considered as one of the subjects that are quite difficult because mathematics is a science that requires ability and reasoning in learning it (3). The fact of the low mathematics learning achievement was revealed by the Head of the Research and Development Agency of the Ministry of Education and Culture (4) that for mathematics subjects the results of the UNBK SMP were always low each year if in 2016 the national average mathematics score was 61.33; in 2017 it dropped to 52.69, and in 2018 only reached the national average value of 31.38 .

On the other hand, issues of morality among adolescents such as narcotics use, pornography, porno-action, student-student brawl, abortion, rape, deprivation, theft, murder, and immoral acts have become social problems which until now have not been completely resolved-coupled with the existence of dishonest behaviour in the world of education by students, for example cheating on exams or homework results, plagiarizing other people's work without including sources, and looking for reasons to run away from responsibility for school assignments given by the teacher (5). These cases are indicative of the weakness of the inculcation of character values in educational institutions, including in mathematics learning.

The teacher has made various efforts, such as using various models, approaches, strategies, methods, or actual learning techniques, utilizing instructional media, and evaluating learning. The scientific approach implemented by teachers in the 2013 curriculum is, in fact, not yet able to overcome learning difficulties and encourage improvement in mathematics learning achievement and student attitudes. One of the factors that are suspected to be the cause of the non-optimal learning approach used by teachers is the lack 
of planning or the low ability to develop learning devices. From the results of (6) research, it was revealed that teachers had difficulty making learning tools in conducting teaching activities. Though planning plays an important role in achieving learning objectives, this is in accordance with (7) statement if students are ready to learn and strive towards achieving learning goals but are not successful, and then the problem can be solved by paying attention to learning planning. Therefore, skills in designing and developing the tools that will be used in the learning process are needed.

Learning devices designed with a student-centred approach can encourage learning processes to be more constructive because they prioritize student activities in learning. This is in line with the opinion of (8) that learning is a constructive process and not the receipt of information. One learning approach that is oriented towards student activities and can improve students' thinking abilities is problem posing. Problem posing is defined as the formation of questions based on context, stories, information, or images that are known. Student involvement through the problem-posing approach is one indicator of the effectiveness of learning (9), and problem-posing activities provide considerable benefits for mathematics learning achievement, problem-solving skills, the level of the problem being proposed, and attitudes towards mathematics (10)

However, what needs to be the teacher's attention is that problem posing in mathematics learning has a high level of difficulty. Difficulties of students in problem-posing have an impact on the use of a lot of time allocation in learning (9), especially when teachers provide guidance for students with low ability. They are coupled with the condition of the availability of student books, teacher books, and LKPD that are not relevant to the RPP problem-posing approach developed by the teacher. In other words, the elements in the learning device are not related to each other. Those are some of the causes of the amount of time that is consumed in the achievement of learning objectives.

One way to overcome the use of relatively long time in learning with the problem-posing approach is to develop learning tools in their entirety and connected between one another, which includes lesson plans, student books, teacher books, student's worksheet, and assessment instruments. While the difficulties experienced by students in submitting problems through the problem-posing approach, one strategy that is thought to be able to overcome them is scaffolding. Vygotsky defines scaffolding as the role of teachers and others in supporting the development of students by providing structured guidance to reach the next stage or level (11). The role of scaffolding in learning, in addition, to overcome learning difficulties, can also foster an attitude of cooperation and responsibility in students.

Based on the description above, the integration between the problem-posing and scaffolding approaches in mathematics learning provides hope for the improvement of learning achievement and character for students. The integration needs to be well designed in the form of learning tools, making it easier for teachers to implement it. In accordance with the opinion of (7), that the design of learning can help improve the learning process. However, the reality on the ground shows that teachers have limitations in developing learning tools. (12) in their research revealed that the learning tools made by the teacher did not support the effort to develop the potential of the students to the fullest including the formation of students' character.

Therefore, researchers are interested in developing learning tools with a scaffolding-assisted problem-posing approach in learning mathematics with the formulation of this research problem. This study aims to determine the level of validity, practicality, and effectiveness of mathematics learning tools with a scaffolding-assisted problem-posing approach for improving the character of students.

\section{Literature Review}

Learning tools play an important role in the success of teachers in managing the learning process because they provide convenience and help teachers prepare and carry out learning in class. This is in accordance with the opinion of (13) that the teacher in the classroom requires a number of learning tools/devices that will help and facilitate the teaching and learning process and provide experience to students in order to achieve predetermined goals. Learning device development activities refer to the syntax of the learning model or characteristics of the approach used to direct the learning activities of students in an effort to achieve the goals set.

One learning approach that can be used to enable higher student activities, train students to conduct investigations through problem submission, engage students emotionally and socially, and is problem-oriented, is a scaffolding-assisted problem-posing approach. Problem posing is one approach to learning, as some of the following experts argue. According to (14) "problem-posing approach allows students to do education. Students shift from simply answering questions to questioning answers through the problem-posing approach of critical pedagogy". Jewett (2019) states: "the problem-posing approach helps students to identify the problem, determine its relevance to them, distinguish the causes of the problem, generalize to others, and create possible solutions for the problem".

Associated with the above understanding, then in this study, what is meant by the problem-posing approach is an approach that involves students actively in learning mathematics through the submission of problems or questions related to the situation or information provided. 
Problem posing situation according to (16) can be in the form of (1) pictures, (2) manipulative objects, (3) games, (4) phenomena or concepts, (5) props, (6) problems, or (7) solutions to problems or problems.

The following outlines several learning theories that underlie the problem-posing approach. (17) learning hierarchy theory; (17) distinguishes the learning patterns of eight types of learning, between low learning types is a prerequisite for the higher hierarchy. The eight types of learning are signal learning, chaining, verbal association, discrimination learning, concept learning, rule learning, problem-solving. Based on the types of learning stated by (17), then problem posing is one of the learning approaches that occupies the highest hierarchy because in this approach students are required to be able to submit problems while solving problems. In the problem-posing approach, students are required to make reasoning and in-depth analysis of the information provided by the teacher.

(18) theory of cognitive development; according to (18), there are three important things in intellectual development, namely structure, content, and function. The essence of the implementation of (18) theory of learning is as follows. Learning is directed to focus on the thought process or mental processes of children not just on the product; the problem-posing approach is a process to understand the problem posed so that it makes it easier for students to solve it. Recognition and recognition of children's role which is very important in self-initiative and active involvement in learning activities; the problem-posing approach demands the involvement of students physically and mentally through observing the senses and mind to process information into problems. Learning does not emphasize practices aimed at making children like adults in their thinking; in problem-posing students are given the freedom to formulate problems according to their level of knowledge. Learning emphasizes the acceptance of individual differences in the progress of intellectual development; the problem-posing approach provides intellectual recognition that the quality of questions or problems raised vary between students depending on their ability to understand information.

One way to overcome the use of relatively long time in learning with the problem-posing approach is to develop learning tools in their entirety and connected between one another, which includes lesson plans, student books, teacher books, LKPD, and assessment instruments. While the difficulties experienced by students in submitting problems through the problem-posing approach, one strategy that is thought to be able to overcome them is scaffolding. Vygotsky defines scaffolding as the role of teachers and others in supporting the development of students by providing structured guidance to reach the next stage or level (11). The role of scaffolding in learning, in addition to overcoming learning difficulties, can also foster an attitude of cooperation and responsibility in students.
Based on the description above, the integration between the problem-posing and scaffolding approaches in mathematics learning provides hope for the improvement of learning achievement and character for students. The integration needs to be well designed in the form of learning tools, making it easier for teachers to implement it. In accordance with the opinion of (7), that the design of learning can help improve the learning process. However, the reality on the ground shows that teachers have limitations in developing learning tools. (12) in their research revealed that the learning tools made by the teacher did not support the effort to develop the potential of the students to the fullest including the formation of students' character.

Furthermore, Vygotsky defines scaffolding as the role of the teacher and others in supporting the development of students by providing structured guidance to reach the next stage or level (11). General characteristics of scaffolding, first: giving support or assistance from teachers or others to students when doing assignments or doing work that they are unable to complete themselves; second: the reduction or gradual withdrawal of support given by the teacher to students; and third: the transfer of responsibility.

The learning theory that underlies scaffolding in learning is Vygotsky's social learning theory. Cognitive development in Vygotsky's view is obtained through two pathways, namely the basic biological processes and psychological processes that are sociocultural (19). Regarding learning, Vygotsky proposed four social constructivist principles as quoted by (20) , namely social learning, ZPD (zone of proximal development), cognitive apprenticeship, and mediated learning. Regarding the principle of mediated learning, Vygotsky emphasizes scaffolding, which means providing assistance to individuals during the initial stages of learning and then reducing the assistance and giving the child the opportunity to take on greater responsibility immediately after being able to do it himself.

The benefits of scaffolding in learning mathematics in addition to overcoming learning difficulties for students, such as formulating problems and solving mathematical problems can also foster curiosity, social concern, and responsibility in students. This means that scaffolding can overcome difficulties in learning mathematics that uses the problem-posing approach during the growing character in students.

Character is the character, nature, or things that are very basic that exists in a person (21). The character can be considered as values of human behaviour related to God Almighty, self, fellow human beings, environment and nationality that can be realized in thoughts, attitudes, words and actions based on religious norms, law, etiquette, culture, and the customs that appear in everyday life. (22) writing entitled "The Return of Character Education and Educating for Character: How Our School Can Teach Respect and Responsibility" emphasizes three components 
of good character, namely moral knowing, moral feeling, and moral action), which are needed so that children are able to understand, feel, and do good values.

As a reference for schools, the Government of Indonesia through the Curriculum Center of the Ministry of National Education conducted a study of noble values originating from the nation's culture and gave birth to 18 (eighteen) character values, namely: religious, honest, tolerance, discipline, hard work, creative, independent, democratic, curiosity, national spirit, respect for achievement, friendly/communicative, peace-loving, fond of reading, caring for the environment, caring socially, and responsibility (23).

The implementation of the problem-posing approach in mathematics learning in addition to being able to contribute to improving learning achievement also allows an increase in character for students. That is because problem posing in mathematics learning has two cognitive stages that are quite important, namely accepting and challenging. At the accepting stage, it can cause students' curiosity about the situation or the information provided. Whereas at the challenging stage, when students formulate problems or questions based on the information or situation provided, it can spur the growth of an attitude of "creativity" and "hard work".

As is the case with the problem-posing approach, the use of scaffolding in learning is inseparable from the values developed in current character education. Optimization of scaffolding in learning can stimulate students' activities, help develop attitudes of social exclusion, responsibility and curiosity in students. Student activities tend to increase due to the establishment of communication or sharing of opinions between students of different academic abilities.

Based on the description above, the use of the problem-posing aided approach to scaffolding in mathematics learning in junior high school can not only improve student learning achievement, but is expected to improve character values in schools such as curiosity, responsibility, hard work, creative, caring social, and independence.

\section{Research Methods}

This research is a research and development that refers to the 4-D model (four D models) by (1). This model consists of 4 stages, namely the stages of definition (define), design (design), development (develop), and dissemination (disseminate). Research and development activities are carried out in the odd semester of the 2019-2020 academic year at Sindue 1 Junior High School, Central Sulawesi Province. The subjects of the study were 27 students of Class VIII Hasanuddin SMP Negeri 1 Sindue.

The products produced from this research and development are in the form of mathematics learning tools with a scaffolding-assisted problem-posing approach that includes lesson plans, teacher books, student books, students worksheets, and learning outcome assessment instruments. To produce good learning tools, it is necessary to go through the stages of expert validation and revise them based on the results of field trials (24).

The instrument used to assess the validity of the learning kit is the validation sheet of the learning kit and validated by three experts (learning experts, media experts, and material experts. Criteria used to state that the learning device has an adequate degree of validity refer to the adaptation results of (25) validity criteria (2016: 159), i.e. if the average value of validity for all aspects of the minimum is in the valid category $\left(2.50<\left(\mathrm{X}^{\wedge}\right)^{-} \_\mathrm{i} \wedge<3.50 ;\left(\mathrm{X}^{\wedge}\right)^{-}{ }_{-} \mathrm{i} \wedge\right.$ is the average value of all validity aspects assessed) and validity for each minimal aspect are also in the valid category $\left(2.50<\left(\mathrm{A}^{\wedge}\right)^{-} \mathrm{i} \wedge<3.50\right.$; $\left(\mathrm{A}^{\wedge}\right)^{-}{ }_{-} \mathrm{i} \wedge$ is the average value of validity of each aspect being assessed).

The instrument used to assess the practicality of learning devices is the observation sheet of learning management and the teacher's questionnaire responses to learning devices. The ability of teachers to manage to learn is said to be adequate if the level of teacher ability is at a good minimum criterion (3.00 TGG <4.00; based on the adaptation of the teacher ability level category by (26). Furthermore, the criteria are set to say that the teacher has a positive response to the learning device if the percentage of achievement of the minimal response agrees at least in the range of $60.1 \%$ s.d. $80 \%$ or are in the high category (27). Therefore, the learning tool is said to be practical if the teacher's ability to manage to learn is minimal and the teacher's response to the use of learning tools with scaffolding-assisted problem-posing approaches in the learning process is positive.

The instruments used to assess the effectiveness of learning tools are the students' character values observation sheet (curiosity character values, hard work, creativity, and responsibility), learning achievement tests, student activity observation sheets, and student questionnaire responses. The learning tools developed are said to be effective, if they meet the following requirements: (1) an increase in the character of students which includes: increasing the value of the character of curiosity, hard work, creative, and responsibility, at each meeting during the learning process; (2) the learning outcomes of students are in the classically complete category; (3) the activities of students in the learning process are in the ideal category; (4) positive student responses to the use of learning tools with a scaffolding-assisted problem-posing approach during the learning process.

Analysis of the achievements of the character values of students in the learning process includes an analysis of the values of the implementation of characters: curiosity, hard work, creativity, and responsibility, through the results of observations made during the learning process. The criteria are set to state that students have an increase in character if the percentage of the number of students who score is 
minimal is good $(2.33<\mathrm{x}<3.33$; $\mathrm{x}$ is the result of the achievement of character values) based on Permendikbud No . 81A of 2013 at each meeting increased.

Analysis of student learning outcomes is directed at achieving classical learning outcomes. Classical learning completeness is achieved if a minimum of $85 \%$ of the number of students reaches a minimum value of 70 (25). Student learning outcomes are declared to meet the effectiveness requirements if it is in a complete category classically.

Analysis of student activity data for each meeting (80 minutes), referring to the criteria for achieving the ideal time for the following student activities.

1. Follow the information closely from the teacher, with the ideal time or WI $6 \%$, and the tolerance interval of the percentage of time the indicator or PWI achievement (1-11)\%.

2. Read / review information in the student book, with 19\% WI, and PWI tolerance interval (14-24)\%.

3. Formulate the problem or question based on the information obtained, with WI 15\%, and PWI tolerance interval (10-20)\%.

4. Formulate and solve problems in LKPD, with $25 \%$ WI, and PWI tolerance intervals (20-30)\%.

5. Discuss/ask friends or teachers, with WI $23 \%$, and PWI tolerance interval (18-28)\%.

6. Conclude the subject matter based on teacher guidance, with an ideal time of $6 \%$, and the tolerance interval of PWI (1-11)\%.

7. Paying attention to the feedback given by the teacher, with WI 6\%, and PWI tolerance interval (1-11)\%.

8. Behaviour that is not relevant to the learning process, for example, sleepiness, seeing the work of a friend, etc., with WI $0 \%$, and a tolerance interval of PWI $(0-5) \%$.

Student activities are said to be ideal if five of the eight tolerance criteria for achieving ideal time are met (25). With a note of tolerance criteria limits 2, 3, 4, and 5 must be met because it is a core activity in learning compared to others.

Furthermore, data analysis on the effectiveness of learning tools related to students 'responses was carried out on data sourced from students' questionnaires on the use of learning tools with a scaffolding-assisted problem-posing approach in the learning process. The criteria established to state that students have a positive response to the implementation of learning tools is more than $50 \%$ of them respond positively to at least $70 \%$ of the number of aspects in question (25).

\section{Results and Discussion}

The activity at the define stage produced information about: the condition of the learning equipment of SMP Negeri 1 Sindue teachers which was incomplete due to the difficulty of teachers in developing it; the character values of students who want to be improved based on information of mathematics teachers and consideration of the limitations of researchers, namely curiosity, hard work, creative, and responsibility; characteristics of research subjects who, on average, have 12-14 years of age have entered formal operations with heterogeneous mathematical abilities and the language used is predominantly Indonesian; material to be developed in research, namely the subject of relations and functions; learner task design in learning through LKPD, practice exercises, and independent assignments;

Activities at the design stage produce prototypes of mathematics learning tools which include: lesson plans, teacher books, student books, student activity sheets, and learning outcome assessment instruments. The results of the initial design of the learning kit are first consulted with the supervisor before expert validation is carried out at the developing stage.

Activities at the develop stage produce revised learning tools based on expert/practitioner input so that they are worth testing. Activities carried out at this stage include expert/practitioner validation and limited trials of the learning tools developed. The results of expert validation on learning tools are based on several aspects, such as components of learning devices, format, language, illustrations, content, and benefits/uses of learning devices. The results of expert validation show that the three sets of learning are in very valid criteria ( $\mathrm{M}>3.50)$, namely: (1) Lesson Plan, (2) Students Worksheet, (3) Instruments for evaluating learning outcomes while the other two devices are in the valid category $(2,50<\mathrm{M}<3.50)$, namely the teacher's book and student's book. Two validators concluded that the learning tool developed could be used without revision, but a validator concluded that the learning tool could be used with a few revisions.

After the results of the design of the learning kit underwent a revision based on the results of the validation and suggestions from the validator, the results of the revision were then trial at SMP Negeri 1 Sindue. The implementation of this limited trial aims to determine the level of practicality and effectiveness of the learning tools developed.

Analysis of the practicality of learning tools based on the results of the teacher's ability to manage to learn, obtained from the analysis of the observations of teacher activities during the learning process. Based on observations it can be stated that the ability of teachers to manage to learn using learning tools with a scaffolding-assisted problem-posing approach at each meeting is in either category or in the range of $3<\mathrm{M}<4$. Furthermore, practicality analysis of learning devices based on the analysis of teacher responses to learning devices mathematics with a scaffolding-assisted problem-posing approach shows that $100 \%$ of teachers have positive responses to all aspects in question (exceeding established 
criteria, which is at least in the range of $60.1 \%$ to $80 \%)$. So, the learning tools developed have met the practical criteria, namely the ability of teachers to manage to learn minimally well and the teacher's response to the use of learning tools with scaffolding-assisted problem-posing approaches in the learning process is positive.

Analysis of the effectiveness of learning tools based on increasing character values consists of the analysis of the achievement value of the character of curiosity, the analysis of the achievement value of the character of hard work, the analysis of the achievement of the value of the creative character, and the analysis of the achievement of the character's value of responsibility. The results of the analysis of the observation sheet for the implementation of the character value of curiosity show that the percentage of the number of students who received a good predicate at the first meeting was $70.37 \%$; second meeting $73.08 \%$; third meeting $77.78 \%$; IV meeting $85.89 \%$; V meeting $88.89 \%$; and VI meetings $92.59 \%$. The results of the analysis of the observation sheet for the implementation of the value of hard work showed that the percentage of the number of students who received a good predicate at the first meeting was 59.26\%; the second meeting 69.23\%; third meeting 77.78\%; IV meeting 81.48\%; V meeting 85.19\%; and VI meetings $88.89 \%$. The results of the analysis of the observation sheet for the implementation of the value of creative characters showed that the percentage of the number of students who received a good predicate at the first meeting was $51.85 \%$; the second meeting $61.54 \%$; third meeting 66.67\%; IV meeting $74.07 \%$; V meeting $77.78 \%$; and VI meetings $81.48 \%$. The results of the analysis of the observation sheet for the implementation of the character of the responsibility value showed that the percentage of the number of students who received a good rating at the first meeting was $59.26 \%$; second meeting 73.08\%; third meeting 77.78\%; IV meeting 81.48\%; V meeting $88.89 \%$; and VI meetings $92.59 \%$. This means that there has been an increase in the percentage of the number of students who received a good predicate of character values: curiosity, hard work, creativity, and responsibility, at each meeting of the learning process.

Analysis of the effectiveness of learning devices based on the results of the analysis of learning completeness shows that from 27 test participants, there were 25 students who managed to achieve a minimum score of 70 or classical learning completeness had reached 92.59\% (exceeding the requirements for fulfilling the effectiveness of learning devices, i.e. at least $85 \%$ from the number of students reaching a minimum value of 70 .

Analysis of the effectiveness of learning tools based on the analysis of the observation sheet on the activities of students shows that during learning activities take place, and students are actively involved so that the dominance of teachers in learning is relatively reduced. In general, the results of an analysis of student activity data show that activities 1 through 7 at each meeting are within the tolerance range, while activity 8 is still outside tolerance and not classified as core activities. Based on the students' activity requirements (five of the eight tolerance criteria for achieving ideal time), the student's activities are in the ideal category.

Analysis of the effectiveness of learning tools based on the analysis of student response data shows that in general, $95.06 \%$ of students responded positively to the use of mathematics learning tools with a scaffolding-assisted problem-posing approach. So, based on the results of the analysis of the pilot activities by referring to all the effectiveness criteria of the learning device, it can be stated that the learning tools developed have met the effective criteria in the learning process.

Disseminate phase is the final stage of development. The results of his activities in the form of socialization of learning tools are limited to mathematics teachers and students of Sindue 1 State Junior High School. Suggestions from the participants of the socialization include a description of the material related to the real-life or environment of students; information that is used as a source of problem-solving while maintaining contextuality, examples of questions in the student book need to be added.

Based on the description of the results of the study, it can be stated that the learning tools developed have met the criteria of valid, practical, and effective. The validity of the learning device is a condition for the suitability of a device to be used in the pilot phase. This is consistent with the opinion of (24) that one of the stages to obtain a good learning tool is through the stages of expert validation/revision.

The practicality of the learning device is an indication of the success of the teacher carrying out all stages of the learning process using the developed learning device. This is in accordance with the opinion of (13) that teachers in the classroom need a number of learning tools/devices that will help and facilitate the teaching/learning process.

The effectiveness of learning tools shows the achievement of learning objectives and research and development activities. All that cannot be separated from the conditioning of students when the process of accepting, challenging, and providing scaffolding during the learning process. This is in accordance with the opinion of (16) that the cognitive process of "accepting" and "challenging" in the problem-posing approach makes students place information on a network of cognitive structures so that it is possible for cognitive structures to get richer. Supports Vygotsky's opinion (20) about one of the principles of social constructivist (mediated learning) which emphasizes scaffolding, namely providing support to individuals during the initial stages of learning, then reducing the assistance and giving the child the opportunity to take over responsibility get bigger soon after being able to do it alone. 


\section{Conclusions}

The validity level of learning tools with the scaffolding-assisted problem-posing approach is divided into two parts, they are lesson plan, student's worksheet, and learning achievement assessment instruments are in the very valid category, while the teacher books and student books are in the valid category. The level of practicality of learning tools is in the practical criteria because the ability of teachers to manage learning in both categories and the teacher's response to the use of learning tools is positive. Furthermore, the level of effectiveness of learning tools is in the effective criteria because it meets all the effectiveness indicators, namely: (1) an increase in the character of students, (2) the learning outcomes of students are declared to be classically complete, (3) the activities of students in the learning process reach the ideal criteria, and (4) students respond positively to the learning tools used in the learning process.

\section{REFERENCES}

[1] Thiagarajan S, Semmel DS, Semmel MI. Instructional Development for Training Teachers of Exceptional Children. University of Minnesota: Leadership training institute/special education; 1974.

[2] Badan Standar Nasional Pendidikan. Peraturan menteri pendidikan dan kebudayaan nomor 21 tahun 2016 tentang standar isi pendidikan dasar dan menengah [Internet]. PERATURAN MENTERI PENDIDIKAN DAN KEBUDAYAAN. 2016 [cited 2020 Mar 2]. Available from: https://bsnp-indonesia.org/wp-content/uploads/2009/06/Per mendikbud_Tahun2016_Nomor021_Lampiran.pdf

[3] Suhartini S, Santoso RH. Pengembangan perangkat pembelajaran matematika untuk siswa smk jurusan akuntansi di sleman dengan pendekatan pembelajaran kontekstual. Jurnal Riset Pendidikan Matematika. 2014 May 1;1(1):69-76.

[4] Friana H. Hasil UNBK SMP 2018 Diumumkan Kemdikbud Hari Ini [Internet]. tirto.id. 2018 [cited 2018 Aug 29]. Available from: https://tirto.id/hasil-unbk-smp-2018-dium umkan-kemdikbud-hari-ini-cK7e

[5] Koesoema D. Pendidikan Karakter: Strategi Mendidik Anak di Zaman Global. 2nd Ed. Jakarta: Grasindo; 2010. 340 p.

[6] Listyawati M. Pengambangan Perangkat Pembelajaran IPA Terpadu di SMP. Journal of Innovative Science Education [Internet]. 2012 [cited 2019 Aug 2];1(1). Available from: https://journal.unnes.ac.id/sju/index.php/jise/article/view/4 $6 / 35$

[7] Kemp JE. Proses Perancangan Pengajaran. Bandung: Institut Tinggi Bandung; 1985.

[8] Glasersfeld E von. Cognition, Construction of Knowledge, and Teaching. Synhese. 1989;80(1):121-40.

[9] Thobroni M, Mustofa A. Belajar \& pembelajaran: pengembangan wacana dan praktik pembelajaran dalam pembangunan nasional. Yogyakarta: Ar-Ruzz Media; 2013.

[10] Rosli R, Capraro M, Capraro R. The Effects of Problem Posing on Student Mathematical Learning: A Meta-Analysis. International Education Studies. 2014 Dec 22;7(13):p227.

[11] Raymond EB. Learners with mild disabilities: a characteristics approach. 4th Ed. Allyn \& Bacon: Pearson; 2012.

[12] Akhlis I, Dewi NR. Pengembangan perangkat pembelajaran science berorientasi cultural deviance solution berbasis inkuiri menggunakan ICT untuk mengembangkan karakter peserta didik. Jurnal Pendidikan IPA Indonesia [Internet]. 2014 [cited 2018 Mar 2];3(1). Available from: https://journal.unnes.ac.id/nju/index.php/jpii/article/view/2 $905 / 2933$

[13] Ibrahim, Muslimin. Pembelajaran Kooperatif. Surabaya: Universitas Surabaya Press; 2000.

[14] McLaren P, Leonard P. PAULO FREIREA: critical encounter [Internet]. New York: Routledge; 1993 [cited 2020 Mar 2]. Available from: https://libcom.org/files/peter-mclaren-paulo-freire-a-critica l-encounter-1.pdf

[15] Jewett BAR. The Impact of a Problem-Posing Approach on Student Engagement in an ESL Classroom in a Mid-Atlantic State [Internet]. [Columbia]: University of South Carolina; 2019. Available from: https://scholarcommons.sc.edu/cgi/viewcontent.cgi?article $=6425 \&$ context $=$ etd

[16] Brown SI, Walter MI. Problem Posing in Mathematics Education. In Stephen I. Brown \& Marion I. Walter (Eds.) Problem Posing: Reflection and Applications. New Jersey: Lawrence Erlbaum Associates; 1993.

[17] Gagne RM. The conditions of learning. New York: Holt, Rinehart, and Winston; 1977.

[18] Piaget J. Piaget's Theory. In P.H. Mussen (ed). Carmichael's Manual of Psychology. New York: Wiley; 1970.

[19] Elliot SN. Educational psychology: Effective teaching, effective learning. 3rd Ed. Boston: McGraw-Hill Higher Education.; 2000. 52 p.

[20] Slavin RE. Educational psychology : theory and practice. 9th Ed. Colombus, Ohio: Pearson/Allyn \& Bacon; 2009.

[21] Majid A, Andayani D. Pendidikan Karakter Perspektif Islam. Bandung: PT. Remaja Rosda Karya; 2012.

[22] Lickona T. Educating for Character: How Our Schools Can Teach Respect and Responsibility. Bantam Trade Paperback Ed edition. New York: Bantam; 1992.

[23] Kementerian Pendidikan Nasional. Panduan Pelaksanaan Pendidikan Karakter [Internet]. Jakarta: Kemendiknas; 2011 [cited 2020 Mar 4]. Available from: https://www.academia.edu/26904390/PANDUAN_PELA KSANAAN_PENDIDIKAN_KARAKTER

[24] Akker JVD, Branch RM, Gustafson K, Nieveen N, Plomp T. Design Approaches and Tools in Education and Training [Internet]. 1st Ed. Netherlands: Springer Netherlands; 1999 [cited 2020 Mar 5]. Available from: 
https://ris.utwente.nl/ws/portalfiles/portal/14472302/Introd uction_20to_20education_20design_20research.pdf

[25] Arsyad N. Model Pembelajaran Menumbuhkembangkan Kemampuan Metakognitif. Makassar: Pustaka Refleksi; 2016.

[26] Widoyoko EP. Evaluasi Program Pembelajaran: Panduan Praktis Bagi Pendidik dan Calon Pendidik. Yogyakarta: Pustaka Pelajar; 2009.

[27] Arikunto S. Manajemen Penelitian. Jakarta: Rineka Cipta; 2005. 